7. Battered back knife, resembling Dr. Sturge's type No. 2. A notch, perhaps for the thumb, has been worked on the cuttingedge near the butt. Length $2 \frac{3}{5}$, thickness of back $\frac{1}{2}$.

8. " A strong point as if for graving, but not a typical graver."

9. A Borer.

10. Possibly a lateral graver. The work at top of implement is battered and near it a notch has been chipped out of the crusted back. This is slightly iron-stained and therefore quite exceptional for this site.

11. A long thin blade, slightly used.

12. Small pointed ridged flake with broad butt and cutting edge used.

13. Small battered back knife, length $\frac{5}{6}$, breadth $\frac{3}{16}$, thickness of back $\frac{1}{15}$. Cutting edge used except near butt.

14. Arrowhead, which I looked upon as, and Mr. Reginald Smith hopes is, an intruder. Like many other pieces from the floor, it has spots of gloss on its surface, which otherwise seems comparatively new.

In addition to the above are shewn:-Five Conical implements with spurs; 3 Conical planes, one with bevelled base; a double plane, shaped somewhat like the keystone of an arch; 3 small scrapers, one nosed, one spurred, one "a good example of the engrailed edge," which appears to be a re-chip; "an implement that reminds one of the Walnut type, two convex faces"; a hollow scraper; "a sub-triangular flake, thickest near the point;" two battered backs, and a few small used flakes.

Most of the specimens are more or less patinated, and many are spattered with splashes of gloss. It seems highly probable that this floor-is of Aurignacian date, and that it has remained undisturbed, on or just below the surface, from the time of its abandonment until the present. There are indications that other similar stations exist in the neighbourhood, but the contents of those so far observed have been scattered and damaged by farming operations.

\title{
THE PLIOCENE DEPOSITS OF THE SOUTH-EAST OF ENGLAND.
}

By W. J. Lewis AbвotT, F.G.S., F.R.A.I.

Read at Norwich, December 13th, 1915.

Several members having suggested to me the desirability, in these days of Zeppelin possibilities, of bringing before the Society an account of some of the additions to our knowledge of Wealden geology, which have accumulated during recent years, especially recently, before they are lost; I trust what I have to offer will prove of interest. Personally I would rather have waited until I 
had been able to work out thoroughly the Lenham-Diestian fauna, and have followed up certain of the fluviatile beds; but unfortunately this may mean years : there is another reason why all this should be widely known, and that is there is a growing tendency in certain quarters to minimize the age of the Crag beds, and to regard them as the marine equivalents of the landward Pleistocene river drifts. This of course reduces both the antiquity and value of the subglacial and sub-Crag discoveries in East Anglia, of which the members of the Society are naturally jealous.

It is, however, very difficult, if not indeed impossible, to estimate the age of the East Anglian deposits without going further afield. For this purpose we must turn to the South-East of England, and more especially to the origin and denudation of the Weald. For it was over this district that the first incursion of the Pliocene Sea was made, and it was the various movements in the earth's crust which have since taken place here, that drove the sea in a north-east direction, thus originating the East Anglian succession, as well as the formation of the river deposits, which formed down the sides of the newly-elevated area. It is therefore certain that, as the Pliocene deposits originated in the Wealden area, that district must form our starting point in the study of East Anglian geology, and consequently of the geology of man.

It is, indeed, exceedingly unfortunate that an area of such inestimable importance should ever have been the one dark spot on the geological maps, and still more so that it should have remained such for all these decades. I shall not be doing my esteemed colleague, the late Wm. Topley, F.R.S., an injustice if I say few realized this much better than he; indeed, he hoped to have been able to re-survey the whole area-a thing which would have been done by others had not unexpected events prevented three Directors General from having it accomplished. When the new survey is made the newly-acquired facts will find a welcome place.

There are three main theories of the origin and denudation of the Weald :- 1 . The plain of marine denudation. 2. The subaerial denudation. 3. The chemical solution.

The first postulates the existence over the Weald of the complete Wealden series aggregating some 2,800 feet; these were succeeded by the Lower Greensand series, the Gault, the Upper Greensand, and the Chalk, making up another 2,100 ft. These were followed by the Thanet sand and the Lower Eocene pebblebed series, adding yet another $100 \mathrm{ft}$,, thus making a total of 5,000 $\mathrm{ft}$. Then an elevation is supposed to have taken place in the centre, throwing up the district into a mountain ridge or dome. Then a mysterious mare innomenatum appeared and attacked the ridge and produced a " plain of marine denudation" till it reached the oldest beds in the centre. We are all familiar with that artistic diagram that has flourished in text-books for the last fifty years, which shows the oldest beds brought up in the centre, and then each succeeding deposit resting upon the shoulders of its predecessor, with a bisymmetry that would serve for an ambidextrous freehand 
copy. A certain amount of sub-ąerial denudation is admitted to have taken place since then, but the main tectonic features are claimed to be due to, and to have originated in, this manner.

But unfortunately for this theory it leaves a number of highly important facts unaccounted for. In the first place, the theorists do not tell us the name of this mysterious sea; nor the geological age in which it existed; nor what became of the vast amount of rock material, covering hundreds of square miles thousands of feet in thickness; nor do they tell what became of the rest of Europe, when the sea rolled six or eight thousand feet above present sea level; nor why this destructive monster should have singled out the Wealden ridge and left the others alone.

I remember many years ago assaying to traverse this "plain": starting at Poll Hill at nearly $800 \mathrm{ft}$. above O.D., in a very short time I had descended between five and six hundred feet, then up again very quickly to nearly $700 \mathrm{ft}$. O.D., then down again to waterlevel, and again $d a$ capo till the "central ridge" was reached. I admit that my feelings were that $I$ had been travelling over anything but "a plain." Of course, I remembered the nature of the rocks over which I had passed, and I decided to take the journey from the south to the centre. Starting from Fairlight church on the top of the Brightling-Fairlight ridge, one saw a valley of dazzling deepness down to water-level, then up again and down again, and again and yet again and again, till the "centre" was reached; and then when one consulted Topley's map one saw repeated lines of anticlines still following each other, and one cannot help feeling that the reason this was called "a plain" is that the more expressive term of "switchback" had not then reached us. That part of these features are really due to sub-aerial denudation and the work of rivers is obvious from the fact that streams still flow in some of the excavated valleys, although at times they run on the anticlines. But if we examine the tectonic structures we shall fail to find the least evidence to support the rising of the oldest beds in the centre, and the newer reposing respectively upon their predecessors. As a matter of fact the oldest beds do not come up to the surface in the centre, and the name Tunbridge Wells Sands has been given to the upper sands. These should not appear at all in the "centre," but nearer the base of the old mountain if the older rocks were brought up to the surface in the centre. One might further add that the "central ridge" is not the one great and only ridge, nor does it bring up so old rocks as the Brightling-Fairlight, nor is it so important. It was this latter that extended over into France. Had this single dome theory been correct, the deposits would have shown in plan on a geological map as a series of rings, the deposits getting older toward the centre, cut through by subsequent river systems, with surface inequalities due to differential denudation; the beds would have risen bi-symmetrical from the south and the north to the centre, ever getting older centrewards; the newer beds would have been confined to the outer edge, and the older ones to the centre. A glance at a geological map will show that nothing of 
the sort obtains! During the many years I have been professionally engaged on the water supply of various parts of the Weald I have often been grieved at the tremendous loss of capital, originating in calculations based upon these erroneous ideas, without either the geologist or the engineer taking the trouble to make sections, before expending the money, or what is even worse, geologists supplying bodies with supposed sections, constructed upon hypotheses, and not upon the structures that really exist.

That many of the features presented by the Weald could not be accounted for upon a plain of marine denudation theory, when so much was obviously due to sub-aerial action, became evident several decades ago, and by many it was abandoned in favour of (II.) a pure and simple sub-aerial origin. The sub-aerialists became a little more descriptive, claiming that the Wealden mountain range rose over 6,000 feet high, more than five thousand feet of which have been removed since plateau man sat upon the dome, or crossed his legs over the mountain ridge, and let fall, now to the right of him, and now to the left of him, the "old brownies" that to-day exist upon the North and South Downs-the whole of this ridge having been removed by ordinary sub-aerial denudation since the Pliocene period. With only the comparatively short period of time which has elapsed since the commencement of Pliocene times, in which all this vast amount of sub-aerial denudation has to take place, we can readily realise the absolute impossibility of this second theory. In the first place, the removed material would have to be taken into the rivers, the size of which would have been so enormous as to have still remained permanent features. But where are they? No such old valleys exist, nor could the present features have originated in that way. Deep valleys or cañons might have been formed, but their old watersheds would have left their mark upon the scenery. Then consider for a moment the enormous length of time this would have required. If we take the mean of the ten most active rivers of to-day, we find they excavate their beds at the rate of one foot in 10,000 years. But remember the size of the modern rivers-realise the many hundreds, nay thousands, of miles long they are, compared with these postulated streams, whose lengths could only have been expressed in tens of miles. Is it possible they could in any circumstances have equalled this mean? And yet we have to account for the removal of over 5,000 feet of rocks over an entire area. This would require, at the lowest estimate, no less than $50,000,000$ years! Further, whither did these big arteries discharge their colossal burdens, representing hundreds of square miles, thousands of feet thick? - enough to fill up a greater part of the North Sea, if it had existed then as now. Of the two sets of difficulties and impossibilities, those of theory II. are, if possible, the greater of the two.

But the finding of the undated Plateau drift by no means ended the features unaccounted for. The discoveries at Piltdown brought to light remnants of a decidedly early Pliocene fauna, at the base of a gravel whose existence had to be accounted for. For 
this purpose it was necessary to bring Pliocene beds over Sussex, conditions many were by no means prepared to admit, as whatever evidence there was for such a thing added a new difficulty to either of the other two theories. Still their occurrence had to be explained : for this purpose the third hypothesis was postulated. It claimed the existence at one time in the area, of the complete Wealden, Greensand, and Chalk series, and Eocene and Pliocene beds; then an almighty anonymous solvent is called into existence, which we are told attacked the Pliocene deposits, and took them away in "solution" ( $\mathrm{sic}$ (not mechanical suspension). Next the obliging solvent turned its attention to the pebble beds, which it digested forthwith; then changing its diet it attacked the lime of the chalk with as great and perfect ease. After this it made other changes, now falling back on sands and now changing to clay and phosphatic deposits : then again its silica hunger re-appeared, and it gobbled up those dense quartzites of the Lower Greensand: then once more back to a calcareous diet, it accounted for the Hythe limestones: yet once more back to clay, and it fed long upon the Atherfield and the thousand-foot Weald clays: then it made its last change back to silica and consumed a large quantity of the Tunbridge Wells Sands. But by this time it had had its fill! Yet omnivorous and unsparing as it appears to have been it could be very merciful ; for finding certain slightly phosphatised bones in the Pliocene beds, either from pity or vanity, it saved them entire and unharmed, not only while it destroyed all similar substances in Pliocene beds, but let the favoured few gently fall vertically as the other beds were destroyed, and all those thousands of feet of calcium, silica, phosphates, and alumina gobbled up, and finally left them in the bed of a river, which then flowed over where many a sea had roared; when they became covered by a gravel of early Pleistocene age! What was the name and nature of that mighty multi-solvent, whence' it came, and whither it went; or how it got the stolen material away, we have yet to discover; all we know is that it commenced its depredations somewhere in the Pliocene period, and was a thing of the past in fairly early Pleistocene times, thus excelling in rapidity of action even the sub-aerial denudation theory!

It is, however, when we examine the lie and condition of the underlying rocks that we find structures for which neither of the foregoing theories can account, any more than they can for the existence of certain deposits and fossils. We have carefully studied these for a long time, and we offer the following as the more probable theory of the crigin and denudation of the Weald, and submit that it is more in accordance with the geological features existing to-day, and calls into being no impossibilities, but only follows out an ordinary sequence, each phase of which has left its mark behind it.

At the close of the Portlandian period, elevation followed, and the area now covered by the Wealden beds then became a huge lagoon, receiving rivers draining the continent, which brought into 
it the materials stripped from the countries over which they passed. The period was a fairly long one, during which the rivers cut down through various formations, the nature of which determined the differences in the composition of the various Wealden beds : now it is a sandstone area that is being attacked, and now clays and iron, such as we find in Belgium. We are all familiar with the old Wealden river that cuts through the Belgium coal-fields, on its way to the Wealden lagoon, and the enormous number of carcases of iguanodon that got buried in its mud. But so far as deposition of the beds in the actual lake or lagoon is concerned, from the Purbecks to the setting in of the depression which brought in the salt waters from the west, it is a continuance of the same peaceful conditions: the beds of ten being deposited very many scores of feet in thickness, and over many miles of area, as level and as thin as leaves of a book. Through vast periods of time it was a seething mass of entomostraca, which at death quietly went to the bottom, to form those entomostraceous paper-shales, where the little tests occupy almost as much space as the interstitial clays. Naturally, as large rivers drained into this old receptacle, it would soon have silted up had not depression kept pace with sedimentation, and that this did so is evinced by the shallow water conditions shown through hundreds of feet of vertical thickness, by the ever-recurring impressions of the feet of the dinosaurs, which walked, rested on their tails, or ran after each other; or again dropped into repose on to their fore feet, to feed on the aquatic, or lagoon vegetation.

I deeply regret that it is impossible to condense into a paragraph or two whole chapters of the earth's history. I should specially have liked to have gone into the concomitant phenomena-such as e.g. the manner in which the lime of the shells of the underlying "roach" was removed, and that marvellous deposition of opaline silica, so analogous to the deposits of the White Cliff opal workings, which has preserved sixty-foot monarchs of the forest; and to that remarkable passage form from the hyaline silica to the collocrystalline flint, found to-day investing trunks of trees; or to the sulphurous emanations which locally exterminated all signs of life, and left behind those prodigious deposits of sulphate of lime.

Reverting to those huge dinosaurs that waded over this shallowbottom lagoon, I do not think their numbers are realised. One quarry alone, about six acres in extent at Hastings, has yielded no less than six species, and judging from the number of limb-bones constantly being found, must have represented hundreds of individuals. It has been suggested that the foreign quartz pebbles indicate estuarine conditions, but why one fails to see. At times large quantities of small white quartz pebbles-a sort of pea-grit-were brought from somewhere by the indraining rivers; but the highly polished and scratched condition of many of the large quartzes, and their being found in quantities associated with skeletal remains of dinosaurs, leaves no doubt as to their being used by these creatures as gizzardstones, despite the hard-worn condition of the teeth of some of them. The constancy and unprogressing nature of the molluscan fauna 
also point to land-locked unaltering conditions with no intercalated estuarine beds. The perfection and delicacy of the vegetation shows that it could not have travelled in a turbulent river; while trees in the form of lignite still attached to their roots point to island conditions. One also sometimes sees pyritic pseudomorphs of animal fæces evacuated on the large insteps of the trees still in position. Here and there one sees a little overlapping and nonconformity, but it is usually easy to see that these are due to differential elevation during deposition; and there would also be channel-currents in times of flood.

This quiescence was brought to a close by a depression wave that set in in the west, travelling eastward, bringing the salt waters with the marine fauna of the Atherfield Clay. Then deeper water conditions are followed by warm deep-sea accumulations teeming with life; and the deposition of the Hythe limestones. Once more a shallowing, and the Folkestone beds followed. With the increased shallowing we get.the muddy conditions of the Gault, with its glorious highly-coloured shells, both cephalapods and bivalves. Then a long continuous depression sets in, and the oceanic deposits of the Chalk sea accumulate. Here again sedimentation and depression play a compensating game; but presently an elevation wave sets in in the west (towards south), lifting the old chalk sea bottom and driving the waters eastwards, so that the further we go in that direction the newer are the beds. (Some beds now existing on the Continent, e.g. the Maestritchean, were never deposited in this country at all.)

But while this movement was in progress an old line of weakness asserted itself, extending in a more west and east direction, which brought up the recently-deposited soft oozy bottom of the Chalk sea, and exposed an island beach to the destructive action of its waves. This made short work of the unconsolidated microglobules of carbonate of lime, and was able to keep pace for a long time with upheaval, the flints alone being left behind, and these ever being ground smaller and becoming rounder. A further general shallowing and now the Thanetian sea is repeating the denuding action of its predecessor. But the culminating rise was too much for the Thanet sea, and the former [sland-pebble-beach became a ridge of newly-emerged land. Rivers now formed north and south from the pebble-clad uplands, carrying the rounded flints north and east over Kent and part of East Anglia, and southward to Newhaven and elsewhere away over land long since destroyed by the English Channel, and they now form a recognisable portion of the beach deposits of S.E. England. It has of ten been claimed that the old "Wnolwich" and "Blackheath" rivers must have been of an extraordinarily torrential character to have worn the pebbles so uniformly rounded. A glance at the delicate spinated shells, which occur in perfect condition in such profusion in these beds, precludes the possibility of such a thing. The rounding was performed upon the old sea-beach, cut off from further supply of flints. 
It is scarcely necessary on the present occasion to follow the movements which accompanied the deposition of the rest of the Eocene beds not directly within our area. If we regard the Hampshire series as Oligocene, and not Lower Miocene, the next series we encounter belong to the phase when the Miocene Sea transgressed northward, bringing its waters over the whole of our district. To the north of us for immense distances there were volcanic activities of colossal extent, accompanying great earth movements and geographical changes, which led up to the Pliocene period. I have always believed that some day we should find in the S.E. of England a succession from Lower Miocene upwards.

The first evidence of the Miocene transgression was discovered by the late Prof. Rupert Jones at Lenham, Kent-hence the name given to the beds. These were found in deep pipes and fissures in the chalk, but the shells have all been removed, and it is only when the sands become sufficiently indurated by the iron oxide to assume the solid form that the casts of the shells are left behind. The same ferrugination of the sands and decalcification and carrying away of the lime was shown forty years ago at Walton-on-the-Naze.

From the first, Prestwich maintained that these Lenham fossils were of Early Pliocene Age, " and having visited the similar deposits with cast-carrying ironsandstones at Diest, and having been confirmed in his opinion by Van den Broeck and other Continental geologists, Prestwich continued to urge the Mio-Pliocene Age of the Lenham beds, and to correlate them with the Diestian of Belgium.

It appears probable that an unfortunate accident occurred and that a piece of Eocene ironstone might have been put upon the tray with Lenham specimens for comparison and there left, which led some to think the rest of the specimens were also Eocene; such a mal-conclusion, however, must have entirely disregarded the palæontology. Subsequently Mr. Clement Reid made a study of the fossils and confirmed their later origin.

The deposits at Lenham and the Downs generally now fill pipes and fissures which form (or rather have formed) lines of drainase in the chalk area. At Lenham they are shown on the face of the escarpment, by the quarrying back of the chalk, at an altitude of about 620 feet. The highest point for miles round is 680 feet, nearly up to which they have been followed. They attain a similar height at Harrietsham. The deposits themselves consist of beds of sand, often glauconiferous and micaceous, with subordinate seams of clay, generally of bright colour, and seams of the peculiar iron sandstones. At times these latter are quite friable and easily crumble to the touch; at others it is hard enough to use with flints for road metal. (I have seen thousands of yards of this broken up for this purpose near East Dean.) Most of the parish boundary stones are made of it, and masses often weighing tons are met with. There are two very different varieties of these iron sandstones, to which we shall again refer. 
From Lenham eastwards, these beds can be traced along the top of the Downs to Folkestone, and sometimes attain considerable thickness. At Paddlesworth they occur at a height of 600 feet, and are some 40 feet thick. The sands are more ochreous here than to the west, and more or less clayey; sometimes pipe-clay is shown, and some quartzose grits, in addition to the iron sandstones. They reappear on the opposite side of the English Channel on the hill tops between Boulogne and Calais, striking inland via Cassel, then sweeping through Flanders to Diest. Westward from Lenham the sands appear to thicken out, and are sometimes less ferruginous; indeed so much is this the case at times that they are mapped as Thanet Sands. My colleague, the late George Holbrook, and I made a microscopic examination of the sands and found a number of minerals present we could not find in the Thanets. By this means we traced these sands practically across Surrey. The most westerly point at which we then found the fossiliferous iron sandstones was, I think, near Newlands Corner, Guildford. Of late years many deposits of ironstone and glauconite grits have been recorded from intervening areas as far west as Netley and Headley Heaths, at altitudes up to 628 feet O.D., the beds sometimes attaining a thickness of 12 feet. The fossils are not so well preserved as in Kent and Sussex, but Mr. W. P. D. Stebbing, F.G.S., has found Nassa, Trochus, Cardium, Modiola, Pectunculus, Tellina, and Thracia; all Pliocene forms."

In places, however, the deposits become far more loamy, and attain a fair thickness. In a pit sunk at Parsonage Farm, Stanstead, above Wrotham, at 760 feet O.D., 12 feet of sandy loam was passed through before the ferruginous conglomerate was reached. It must be remembered that upon the further elevation of the old Lenham-Diestian sea-bottom consequent rivers would form, cutting into the old marine deposits, so that marine shells might be found in the old river deposits. It is not always that chemical absorption has been active, although it generally has.

In cutting an extensive trench above Wrotham, and excavating for a reservoir, a number of fairly large recognisable broken shells were found, and I have no doubt that many have been thrown out in the recent trench-digging by the Army along the crest of the Downs. I have found the iron sandstones at most of the highest points on the North Downs. At Wick Farm, at $680 \mathrm{ft}$. O.D., they often show a deep red colour and abound in casts. The shells here appear more broken than in many other localities, as if subject more to the action of waves upon a shore, although double valves are not wanting. An interesting section of undisturbed Lenham-Diestian beds occurs on the North Downs, near "The Rising Sun,". above Kemsing, at an altitude of $670 \mathrm{ft}$. O.D. In the fields adjoining there are large quantities of the characteristic ferruginous sandstones; sometimes quite large masses of it occur. At the back of the public-house there is a sand-pit cutting into the underlying

* Pro. Geo. Assn., XVI., 524-526. 
sands, showing their relation to the sandstones. At Otford Mount the sandstones (cretite conglomerates) occur at a height of $660 \mathrm{ft}$. O.D.

We may, perhaps, here stop with profit to consider the curious actions that have taken place in these sandstones. In a paper on the Admiralty section * the remarkable metamorphic changes effected by certain limonitic waters are described. From the old ferruginated Lenham-Diestian Sea beach-deposit the lime has been so completely removed that all traces of it have disappeared, and subsequently the lime of the shells, and all we have now are the perfect hollows once occupied by them. To these we shall refer again.

For many years I have also been studying the changes that take place in flint. I may, therefore, perhaps be allowed to digress a minute or two upon some of these:-

Silica may be regarded as a dimorphous substance, i.e. as occurring in two states, and mixtures, and passage forms of these. The first is crystalline, the other colloid; the former is only very sparsely soluble with difficulty; the latter readily so. Sugar is a parallel case: sugar-candy is in the crystalline state, the individual crystals can be nursed till they can be measured by inches. Barleysugar is in the colloid state. There is another state of silica-a passage form between the two, the crypto-crystalline. Clear quartz is in the crystalline state. Opal is in the colloid. Flint is a varying intimate admixture of the two; hence Collo-crystalline. Chalcedony is in the crypto-crystalline state. Chert is the latter in the presence of inclosures; the nature of the enclosures and the mode of aggregation give rise to a number of varieties-as nuclear, spiculiferous, radiolarian, porphyritic, pegmatitic, etc. When the enclosures are largely or wholly sand grains, we get cryptocrystalline-quartzites. These latter play an important rôle in the history of the denudation of the Weald.

Each of these forms of silica and each of the varieties of flint is susceptible to different metamorphoses. The early stages of these processes are confusedly referred to as "patination." The six principal of these I call :-1, Glaze. 2, Cretaization. 3, Porcellanization. 4, Opalization. 5, Jasperization. 6, Lyditization.

When a solvent acts upon a flint it withdraws a certain amount of the colloid silica and leaves behind a micro-skeleton, largely composed of the crystalline state. When the light falls upon the micro-granules, most of it is reflected back to our eye, giving the impression upon the retina we call white. We see this process in all stages, from a cloudy discoloration of the flint through a fair thickness (when the change is usually miscalled patination) till all traces of the flint disappear. When the absorption is quite complete (say, in vitreous flint), the resultant material is as white and as soft, or softer than the softest chalk. This is the process for which I propose the term cretaization, and for the resultant substance,

\footnotetext{
* Pro. Geo. Assn., Vol. XII., 1892.
} 
cretite. Not that it is really changed to chalk, but to a state closeiy resembling it. In these Lenham-Diestian sands there was originally very often a large quantity of flint pebbles-generally rather smallboth angular and rounded, which have suffered cretaization, and are now so soft as to yield readily to the thumb-nail. I have never seen these cretite conglomerates in any other deposit, although absorption of colloid silica is always taking place whenever necessary conditions obtain. But the identity of both the castcarrying ferruginous-sandstones and the cretite conglomerates, all over the district (and extending into Belgium), whether upon the east end of the North Downs, or the west end of the South Downs, is really remarkable. We have thus two essentially characteristic Pliocene rocks, in addition to the Pliocene phosphatized bones, teeth, and shells, to enable us to fix the age of the deposits under consideration.

In the breaking up of these deposits naturally they might occur as derivatives in Pleistocene beds; but it is generally impossible to make a mistake between a deposit in situ and an erratic fossil. At the base of the Medway at Aylesford these Lenham-Diestian fossils (rocks) occur in large quantities, in some places, yet no one could mistake their derived origin. But even when derived it shows the existence of beds of Pliocene Age in the area cut through by the later rivers.

Although in Belgium the iron in these beds is sometimes largely in the unaltered glauconitic state-and in coming west the dual metamorphoses appear to be greater, the shells disappearing pari passu with the oxydizing of the iron, and its changing from the "black" green to red-yet when we remember how large a quantity of iron has been produced by the Wadhurst Clay series, so great indeed as to have called into existence the old iron industries of this country-and how largely this series has suffered denudation, we feel that its claim to be regarded as the source of the iron of the Crags cannot be ignored, especially as the Red Crag is separated from the Lenham by the White Crag. Still it must be remembered that masses of "Red Crag" dredged up from the North Sea are still in the unoxydized state.

Upon the elevation of this old Lenham-Diestian sea bottom into uplands all the phenomena of land drainage followed. The ferruginous old beach would highly charge all drainage-waters with that metal-even the underground permanent waters-with the result that deposits of rich bog iron-ore would be deposited at these levels and along old drainage lines. Rich, solid, massive bog ironore now rests upon the old marine deposit that lies upon the highest portions of the South Downs. The formation of this deposit takes us back to the time when the old sea bottom was slowly emerging from the Lenham-Diestian sea. Similar deposits--though not of such fine quality - are still forming at the drainage levels over extensive areas of the Wealden seaboard receiving the drainage from the ferruginous Wadhurst Clay. We have-previously referred to the fact that the examination of the underlying Wealden rocks 
reveals in the most strlking manner the evidence that the earth's movements have travelled as waves. Sections through some of these waves have revealed over 50 inclined step-faults, and as the beds - although originally exceedingly even and level — of ten alternate in colour with frequent layers of white, they form a wonderful picture. Had it been a case of simple elevation the domed upper parts might have opened, and had they settled down again the new filling might have suffered an upward squeeze; but here we see the beds are lifted up and then let down again as the wave passed, each block falling behind the one in front of it. This effect can be shown experimentally. The more we examine the nature of these earth waves the greater their similarity to water-waves becomes. *Topley's Map of the Weald shows the anticlines, not like rectangular faults, but bow-fronted waves following one behind the other. If we notice a water-wave we shall see that in front of it there is a depression. We should therefore expect to find the Diestian and Crag series in Holland plunged far below their original depths.

One set of these waves towards the end of the LenhamDiestian period travelled from south-west to north-east. It can be readily conceived that as these waves travelled in this direction they drove the sea to the north-east, with the result that the Crags would be deposited in the order in which we know them to exist in the Eastern Counties, the old land surfaces being transgressed upon by this somewhat land-locked sea; and when the depression extended far enough to the north, more boreal species would be added. $\mathrm{Mr}$. Clement Reid has called special attention to the more southern facies presented by the fauna of the Lenham-Diestian beds as compared with the Coralline. His figures, ${ }^{\dagger}$ however, are a little difficult to follow. In his tables he gives only 59 species; of these 24 per cent. are confined to these beds, 29 species occur in the Diestian, and 24 are common to the Diestian, Lenham, and Coralline Crag, and 41 are found in the Coralline Crag. In other lists he refers to a greater number of species, and as before remarked makes a special note of the southern aspect of the fauna. Since this date a much larger amount of work has been done in these beds. I regret I am unable to give lists to date. I am obliged, however, to say that my own work points to a more Miocene aspect, the species on the South Downs being rather different from those on the north. Those on the table are from the South Downs, and are casts made with dentist's wax, which if used quite hot gives excellent results-but it must be quite hot-and when made are practically indestructible. Some 20 years ago I passed over a lot of my Lenham material to my esteemed colleague Mr. A. S. Kennard, but unfortunately he has been so engrossed in putting the British land and fresh water mollusca upon a scientific basis, that he has not had time to work them out. Those which I have

* Mem. Geo. Sur. E. \& W. Geol. of Weald. Q.J.G.S. LII., 748 et seq. t Mem. Geo. Sur. Pliocene Deposits of Brit. 
obtained from the South Downs certainly have a more Miocene aspect.

It is probably the formation of the early Pliocene consequent rivers down the newly-elevated land that is of such superlative importance and interest to prehistorians; for it is in these that the evidence of the earliest traces of man's immediate predecessors, associated with the contemporary fauna, have been found. The first of these Pliocene rivers was discovered in Dorset, and yielded elaphine creatures; the first of which was identified as E. Meridionalis, from which fact I suggest they should be called the Meridionalis gravels; other elaphine creatures have also betn tound in them of an older form or forms. It is to this series that the lower Piltdown gravels belong, which have furnished not only the old Pliocene mammals, but one of the well-known predecessors of man-Eoanthropus Dawsoni." Here the lowest bed is about eight inches thick, and cuts into the underlying Tunbridge Wells Sands, mixing the materials, i.e., the original sand, the clay and the flints, much in the same way as it did at Hastings. Here also were specially large flints. But so far as I am aware the materials did not here re-form into a hard sand-rock, with the result that there was more circulation and flow of the solvent, which at tacked the soluble colloid part of the flint (as is the case in some of our oldest gravels at their base), leaving the flints soft and friable, but also leaving them in a state capable of absorbing a large quantity of iron, with the result that these flints look more like a granular ironstone; but true jasperizing has rarely supervened, and one can often easily scratch them with a knife. This bed is followed by a dark brown ferruginous gravel, but far more sandy than in the deposit at the back of the East Sussex Hospital at Hastings; the flints are the same dark brown colour. This rests upon the eroded surface of the lower bed and is about 18 inches thick. It is claimed to contain a marked number of tabular flints. I must, however, say that I never saw a piece of tabular flint from this bed, but many of the flints have been subject to what I call "platy fissure," thus giving rise to pieces of more or less tabular forms. But the two things are, of course, so very dissimilar and have so different an origin that these flints have no zonal value. It was in this bed, in hollows in the underlying, that Eoanthropus Dawsoni was found, together with Elephas Meridionalis, and another probably older elaphine creature, Rhinoceros etruscus and avernensis, and a Castor.*

The next bed is a sandy loam some three feet thick, but its colour is lighter than the Hastings loam in places, as the iron appears to have segregated out into lenticular patches which then become much darker. Flints are found in this bed here rather more plentifully than (in the correlated bed) at Hastings, or they are larger and more subangular and so appear to be in greater profusion. It is, however, certain that this bed is not in the undisturbed state of the Hastings loam, and has been cut up in the history of the

* Q.J.G.S., lxix. pp. 117-151, 1xx. 82-99, and lxxi. 144-149. 
valley in which it now reposes. Upon the idea that boldly-facetted flints must be of Palæolithic age, this deposit has been assigned to that period. This hypothesis, however, I regret I cannot for a moment accept; one has only to see the worked flints from the Cromer Forest bed to realise its fallacy. These beds pass upwards into the surface soil.

Naturally since this time there has been a great deal of differential elevation, with the result that these Pliocene deposits are now found at very different altitudes, and the deposits have been subject to very different dynamic agencies. These movements are beautifully shown in the newly-discovered Pliocene deposits in the Hastings district (to be described a little later on), from which it becomes evident that the oldest Pleistocene Palæolithic deposits in that neighbourhood are long subsequent to this period, and that both surface-levels and local dips of rocks were very different in Early Pleistocene times from those obtaining away back in the Pliocene period.

Upon both North and South Downs there exist old sunken river deposits of this age. Sometimes they have been cut through by quite old Palæolithic rivers, and in some cases, such as the Darenth at Otford, the old channel has been retained through the successive ages. Upon both shoulders of this old stream we find the Pliocene plateau drift, which was cut through over $500 \mathrm{ft}$. before the E.primigenius gravels were deposited.

Another of these old streams, or possibly an eastern meandering of this one, passed over to the north of Wrotham; several pits have been sunk here through the loamy sand to the basal conglomerate, which at this depth has not been oxydized. Here the flints are a dark greenish brown, and the chipped edges are a more greenish colour, rather glazed. The greater part of the flints are hard worn, though many are subangular and very contused, presenting a deep contrast to a few that have been found with sharply-flaked edges, devoid of contusion, and of a definite outline. We must, however, remember that coincidence of outline, even over a multitude of specimens, by no means proves human shaping. These worked flints I regard as the Stanstedian stage." The chipping on these flints does not indicate the knowledge of the rounded hammerstone, and hence they are pre-Palæolithic.

At Ash and many other places the iron in the flints has been further oxydized, and here they assume the characteristic orangered-brown. In the lower Ashian stage there are still no signs of Palæolithic work, which characterizes the Upper Ashian, nor of the remarkable transitional work of the Fawkhamian stage.

Probably the most interesting river deposit in Kent, and one that has not received a tithe of the attention it deserves, is to be found in the Ingress valley, Swanscombe. I first discovered it some 25 years ago, when its essentially Pliocene fossils arrested my attention. I

* The classification of the British Stone Age Industries. Jour. R.A.I., Vol. XL1., 1911. 
then thought as I do now, it could never have been a Thames deposit, but that it originally formed one of the Pliocene streams that flowed from the Southern Highlands. It was for this reason that I was obliged to refuse my friend, the late Mr. Stopes, incorporating my lists with his," as I felt that no one at the time realised the importance of this remarkable deposit. 1ts chief fossil is a Miocene Neritina, which occurs by the million. It is quite inconceivable to me that this creature should have formed the mass of a formation laid down by the Thames, and yet for that fossil never to have been found in any admittedly Thames deposit. But this is by no means an isolated earlier fossil; we have there a Paludina which we know only from the Pliocene deposits; and another not yet found anywhere else in the country. Many other of the species are either known only from Pliocene, or not from Pleistocene deposits. The Unio fauna is quite as interesting. I have spent a great deal of time on conchometric measurements of the members of this genus, and I am confident that we have here a number of well-marked species that have never been found in Pleistocene deposits. It was here also that I found that essentially Pliocene giant rodent Trogontherium cuvieri." There are other mammals that await a thorough working out. It is only right, however, to mention that a number of species occur here which are also found in the Pleistocene, and implements of a variety of types from prePalæolithic to Acheulian. ${ }^{+}$It is certain that in some parts of the deposits there.has been an amount of mixing up, and redepositing in later times has taken place ; but even if we grant this we have still an essentially Pliocene fauna, whose existence can only be accounted for on the assumption of an old Pliocene river.

We will now return and consider the other Pliocene fluviatile deposits of Sussex. At the west end of St. Leonards we have a deep valley which now carries the Hollington stream. The curious way this is truncated by the Brightling-Fairlight ridge, the occurrence and extent of a characteristic loam, and a heavy flint gravel, shows that it has been robbed of its gathering grounds or basin, by the upheaval of the Brightling-Fairlight ridge. This is the most important ridge in the Weald, and the one which formerly stretched over into France, forming the water-shed between the Great North and the Great South Rivers. At the bottom of the valley the present stream cuts into an old flint-iron pan, which can be traced for the entire length of the valley. Now as this stream is at present entirely, and so far as we can see always ran, in the Lower Wealden rocks, it must date back to a time anterior to the removal of the last vestige of the chalk flint. If we examine the oldest Palæolithic drifts of this part of the country we find them to be composed exclusively of hard worn iron and sandstones, and "blue-stone" (sedimentary quartzites): practically the only flint we find has been worked and imported into the neighbourhood.

\footnotetext{
* Jour. R.A.I. XXIX., N.S. ii., 1901.

†Geo. Mag., 1902, p. 385.
} 
When we realise the great depth of this valley, and see how quickly it is truncated by the Brightling-Fairlight ridge, it becomes certain that the original valley antedated the formation of the ridge, and also long preceded the oldest palæolithic deposits in the neighbourhood.

The "pan" as usual is followed by a beautiful rich chocolate loam, which is to be found on the east and west watersheds of the present stream at 150 feet and upwards above the basal conglomerate, but they have been carried up with the ridge to a height of over 500 feet O.D. It is maintained by many that the Pleistocene loams never occur at more than $150 \mathrm{ft}$. or $200 \mathrm{ft}$. above O.D. Upon this hypothesis we may claim therefore that we have conditions here never before found. In various places in the Weald I have had to survey I have found these loams up to great heights on hill tops. The inclusions in this loam point to a non-local origin.

Although it was the West St. Leonards deposit which led my colleague, Mr. Charles Dawson, to study the gravels in his own neighbourhood with such superlative results, sections recently laid bare at Hastings are more complete and interesting. Upon the geological map two faults are shown at the back of the East Sussex Hospital; here very extensive sections have recently been laid bare by the cutting of a double sloping road along the cliff face. Two beds of dove-colored indurated clay and undisturbed sandstones can be traced over the whole area, and very much further, which shows that the faults with their hundreds of feet of movement have no existence. When the cliff was first cut through the beautiful chocolate loam already referred to abutted against an almost vertical wall of local rock (the old Pliocene river bank). When the Survey Officers saw this they probably mistook it for Wadhurst clay, faulted against the Ashdowns. I admit it presented a puzzle at first sight. As the loam was over $40 \mathrm{ft}$. in thickness, and at the bottom current-interbedded with the re-deposited sand-rock, it looked as if it were a virgin loam; upon the sight of the pebbles of flint, however, it became evidently of post-Cretaceous Age. Fortunately another long section was cut along the Bohemia road at about $140 \mathrm{ft}$. O.D., bisecting the line marked for the extension of the white rock fault. First the chocolate loam was encountered; below this there was hard worn dark brown flint gravel, and below this a dense ferruginous flint pan of a beautiful orange red-brown colour, such as one sees in the Red Crag, presenting a complete section of an old river channel. It was a never-to-be-forgotten sight how the bottom of the stream cut into the underlying sandstones and churned them back to sand, amongst which were deposited large sub-angular flints. So great has been the subsequent pressure, and so long the time that has elapsed since, that the sand has been once more pressed back into sandstones (a thing never seen in Pleistocene deposits), in which the flints were now so firmly embedded that steel wedges had to be employed for their removal, and I failed to convince the workmen that the flints had not been formed there. 
To convince me of my wrong a workman exerted considerable labour with his pick-axe, in the doing of which he struck one of the imbedded flints several times, fracturing off a splinter or two. Judge my delight when afterwards examining it and cleaning off the sandrock, I saw it had been worked to a point. I am fully aware that it would not be accepted as an artifact by everyone; there are some people who accept nothing but the masterpieces of Palæolithic art, and I have come across some who reject everything except the finest bi-symmetrical polished axes. There is practically nothing they will accept, especially if they do not happen to have found it themselves. These chronic "reject-alls" are nearly as bad as the "accept-alls," to whom the fortuitous coincidences of nature's subomnipotence, with some form which they call a "type," for which their ingenuity has suggested a use, are the infallible hall-marks of man's work; to them a directing hand in the removal of the flakes, any relation between striking-face, striking-plane, and flaking-plane are fanciful terms of the supercilious. The axes of contiguous flakes in a series may fall through all azimuths; the equal claim of the hand that holds with the hand that strikes has never for a moment been entertained. To those of us who approach the question from a lithoclasiological point of view, outline is little or nothing, bulbs of percussion, conchoidal-ripplings, eraillures, resolutions ("hinge-joints"), and many other things are as much the property of the multitudinous forces of nature as of man. What we look for is not the one-handed promiscuity of nature, but the evidence of an intelligent ambidextrous co-ordination, the regulating of the grip of the one hand to the blow of the other." In the fabrication of an implement, as in so many operations of life, the work of the left hand is far the more important. While that of the right is so restricted that probably in an hour's work the striking plane would not vary more than a few degrees, the accommodation of the left would extend, not only to 360 degrees but every direction.

I think we may fairly assume that the first assistance the anthropoidæa obtained was from clubs and stones, although we may not be able to say which was used first; if we note that the former are now used by the higher apes, and stones by their lower cousins, we might conclude that hand-stones were first used. It may not be generally known, but it can easily be demonstrated, that if we take a pebble in the hand and strike it hard upon a solid stone, if it presents a point of impact which is a segment of a sphere we should put on a point, and that point would be a cone. If, however, the point of impact is other than a segment of a sphere, or the axis of the striking plane is distorted (ricochets), then we produce a facetted cone for a point. The facets may vary in number from three to say a dozen, but the point may be absolutely acute; some I have will cut a sheet of paper without tearing it. I have no doubt that these pointed hand-stones were the first to be employed by the predecessors of man, $\dagger$ and from these the holoclastic Palæolithic axes

* "Man," 1909, 88.

† Jour. R.A.I., Vol. XLI., p. 462, et seq. 
might naturally have been evolved. Let us now consider the implement in question from the lithoclasiological point of view: originally the flint was a gibbous, slightly oblate, ovoid, with broad rounded edges, presenting an excellent though not altogether perfect handhold; a few blows from one side made it more sphenoid, and then a few more at the broader end perfected the grasp, and left it an easily-used hand-wedge. But it was not a chisel-shaped wedge that was wanted, but a piercing point, and it is in the putting on of the two sides of the point that intelligence is brought into play. All the blows putting on the one side are struck from the same face, then the flint is turned in the left hand and blows administered on the reverse face. As the first sphenoid working had been effected on one side, there was probably-or indeed certainly - too much one-sidedness to allow of the secondary working to extend to the tip if struck from that side; the flint was therefore turned in the hand and the point finished from the other side. It is greatly to be regretted that the pick of the workman struck the implement at the point, but only about a square inch of the original surface has been damaged, and the history of its working is still preserved.

An interesting feature about this implement is that in the sphenoid working it became more protuberant on one side than on the other, and when held with the flatter side in the palm of the hand would form an excellent hammer-stone. To this purpose it was subsequently put, in which capacity it did magnificent service; the exposed parts when held in the hand show signs of an enormous amount of work. This battering passed over the old worked surface, but stopped in the position it would have done had the tool been used as a hammer-stone.

It is certain the battering could not have preceded the flaking because it extends over some of it, while it is equally impossible for it to have been due to the promiscuous batterings in the various operations of nature, as the beautiful highly-glazed vitreous flint is just ready to register the slightest tap!

One word about the character of the flint. As is often the case, the flint was a mixture of vitreous and normal, with small patches of granular; naturally the metamorphoses of it have been very different in the different parts. The vitreous has now opalized, absorbing sufficient iron to become a bright highly translucent chestnut-brown. In places which have been apparently unprotected cretaization has supervened. The normal has suffered jasperization, and is now from a full to a deep brown colour. The absorption has naturally been much less in the small granular islands, which are therefore of a lighter colour. The general effect is that of a very rich lustrous dark red-brown, save of course where the white cretaization has supervened.

The great earth movements which have taken place here since the deposition of these old river deposits, and before the present tectonic structures obtained, are very remarkable. There is now a difference of $80 \mathrm{feet}$ in the altitude of the bottom of this river bed in about 300 yards; while although its bottom is visible on one side of 
the road to the level of which it descends, it is practically lost on the other side of the high embankment. The deposits can be picked up again all over the district up to over 500 feet O.D.

On the site of the new hospital to the S.E. the loam is succeeded by a coarse free muscovite quartz-flint grit; the whiteness of the muscovite and the quartz give it a bright light colour. The little blebs are usually from about 1 to $2 \mathrm{~mm}$. in diameter. Quartz-free grits occur in the Wealden beds at several horizons, generally forming "bone beds," but they are quite different from these, and we at once miss the bright white muscovite in them. They are also more coarse, and contain blebs or pebbles of phosphatized bones and teeth, and they are harder worn than the components of the Pliocene grit. The sandstones cut through in this Bohemia Road section revealed over twenty faults, and the dissimilarity of the beds on opposite sides of them evinced there had been great lateral as well as vertical displacements, indicative of the wave-like movements to which we have referred. Sometimes the waves of different ages intersected, when very curious cavities resulted. In places the Pliocene loam, pan, and gravel were let down into the fissures and exhibited subsequent twirling and twisting.

These beautiful warm-brown hard-worn flints all over the Weald had long been a puzzle to me. Prestwich was of the opinion that they indicated a baptism, and as they occur generally somewhat sparsely and quite unassociated with Palæolithic drifts, and on the surface where Neoliths are found beside them, he concluded the submergence took place in Neolithic times. We are now able for the first time to trace these ubiquitous flints to their origin.

There are several Qther well-known gravels in the S.E. of England whose origin has always been a mystery, and to account for which various hypotheses have been suggested; but the deposits fit in with none of the usually accepted ideas, yet will find their right place as members of the Pliocene series. These I hope to describe on a future occasion. I have already had to curtail this lengthy subject, and to make statements where I would rather have detailed the evidence, but I trust I have said enough to establish the existence of Pliocene deposits in S.E. England, and supplied new material for their origin and history.

Following along the lines here suggested, we can trace a sequence of the earth's movements and their action upon the great main arteries: how the rivers first originated, how some of them say-e.g., the Proto-Rother fought against the rise of the Robertsbridge ridge-and watch the time for which it was successful; until the rising land-wave was too much for it and turned it at right angles to the east. We can follow this east-flowing stream till the great downthrows broke the ridge, and once more made the Rother a south-flowing stream. We can trace the cutting back of the subsequent streams from this, and watch the way one of them cut back till it captured a relic of the Proto-Rother, and thus originated the Brede; and all this becomes so much more interesting 
from the hundreds, or even thousands of flint implements, belonging to the various races down to the Magdalenian who saw these changes. Then the Hastings Kitchen Midden" men take up the tale, which they tell in incomparable detail and completeness, and bridge over the sequence to Early Neolithic, leaving no time, I fear, for the great hiatus we formerly believed in, between the Palæolithic and the Neolithic Ages.

I suppose I ought also to remind you that in Sussex we have associated with, or separating the various races, those evidences of arctic severity of climate, regarded as belonging to Glacial Periods, in the form of erratic, volcanic, metamorphic, and foreign and northern Palæozoic rocks, many of which are deeply striated, ground, and facetted, $\uparrow$ quite equal to those of the Eastern Counties, all of which link S.E. England with East Anglia in one inseparable whole.

\section{CONE CULTURES IN THE WENSUM VAlLEy.}

Read at Norwich, December 13th, 1915.

$$
\text { A.-Hellesdon. }
$$

By W. G. Clarke and H. H. Halls.

Early this year we discovered a station, apparently with a homogeneous culture, on an arable field in the parish of Hellesdon, about half-a-mile above Norwich. The field, which has an area of about 12 acres, is on the north side of the river Wensum, from which it is about 74 yards distant at the south-east corner of the field, and 150 yards distant at the south-west corner. Between the field and the river is alluvium $12 \mathrm{ft}$. above O.D., and the field is $2-3 \mathrm{ft}$. higher. Flint implements, flakes and potboilers are very abundant on the lower part of the field, thin out rapidly on the higher part, and occur sporadically on the more elevated ground in the immediate vicinity.

Several thousand cones, flakes and chips were examined on the spot, but the number of implements retained was 482. The flint of which they are made is easily divisible into three groups. The sole group patinated is one containing only 4 per cent. of the implements, which consist of blue-patinated and iron-moulded specimens.

* Jour. R.A.I., XXV. Nat. Sci, 571, 93 (42, 25). “ Man," 1909, 103.

† Pro. Geo. Assn., Vol. XX., p. 3, 1907. 